\title{
Educação Artística
}

\section{ANA MAE BARBOSA}

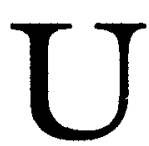

m dos mais tardios investimentos da USP foram as Artes, em contraposição à maioria das universidade brasileiras, que cedo criaram seus cursos de Artes, e à própria organização do Ensino Superior no Brasil. Depois da Escola Militar e das Faculdades de Direito e Medicina, a primeira escola superior voltada às humanidades no Brasil foi a de Belas-Artes, encomendada por D. João VI e pelo Marquês de Marialva a um grupo de artistas franceses, bonapartistas, que de certa maneira buscaram no Rio de Janeiro refúgio das perseguições políticas depois da derrota de Napoleão Bonaparte.

Esta foi, na História da Educação do Brasil, a primeira Missão Francesa. A segunda, que criou a Faculdade de Filosofia, Ciências e Letras e a Universidade de São Paulo, composta por professores de cultura muito ampla, despertou nos estudantes grande interesse pelas Artes embora não incluísse artistas. Além disso, os professores franceses deixaram bem sedimentados os estudos de Estética e Sociologia da Arte, posteriormente continuados por seus talentosos e bem preparados exalunos. Entretanto, o ensino da Arte somente seria especificamente sistematizado na USP trinta e cinco anos depois, com a criaçáo da Escola de Comunicaçóes e Artes (ECA).

Nos anos 60 a idéia, e o plano, era criar um Instituto de Artes, mas vivia-se o difícil tempo da ditadura e aqueles que detinham o poder na Universidade decidiram - em vez disso - criar uma Escola de Comunicaçóes Culturais. Náo foi sem luta que os professores criadores do projeto para o vencido Instituto de Artes conseguiram agregar as Artes às Comunicaçóes e até hoje se discute a propriedade dessa parceria.

Muitos entre os das Artes querem a separação, que chegou a ser tentada infrutiferamente em 87-88. Acreditam que o crescimento das Artes está sufocado pela prioridade que é sempre dada à área de Comunicaçóes, cujo número de alunos aumentou rapidamente em decorrência de as garantias de trabalho nesse campo serem aparentemente maiores. Outros acham que a separaçáo enfraquecerá as duas partes, frente ao grande poder das áreas de Ciências e Tecnologia. Outros, ainda, condenam a mera separação e anseiam pelo retorno à idéia da criação de um Instituto de Artes que aglutine as equipes de História da Arte, da Faculdade de Arquitetura e Urbanismo; de Estética, da Faculdade de Fi- 
losofia, Letras e Ciências Humanas; de Artes Cênicas, Artes Plásticas, Música e Cinema, da ECA; além da Escola de Arte Dramática, em nível de $2 \circ$ Grau (criada por Alfredo de Mesquita e posteriormente assimilada pela ECA), e, ainda, a criação de um Curso de Dança com terminália específica.

Vivemos hoje algumas situaçōes esdrúxulas, como o caso do Cinema, que pertence às Comunicações na graduaçáo e às Artes na pósgradunção. Por outro lado, os grupos de estudo mais aprofundados de dança estão no Instituto de Psicologia e não na ECA. Esses são assuntos que precisam ser discutidos com mais sistematizaçáo na USP, talvez com outro enfoque, sem propósitos separatistas, mas dando-se ênfase a um projeto unificador das Artes na Universidade para explicitar uma comunalidade de interesses.

Em 1992, pela primeira vez, a Escola de Comunicaçóes e Artes, a Faculdade de Arquitetura e Urbanismo e o Museu de Arte Contemporânea trabalharam oficialmente juntos para a realizaçáo de um evento o I Congresso sobre o Ensino das Artes nas Universidades -, do qual também participaram professores de Estética da FFLCH e de História da Arte do Curso de Arquitetura do campus da USP em São Carlos. Coisa modesta, mas muito bem pensada, que demonstrou as enriquecedoras possibilidades do trabalho em conjunto. Um livro com as principais palestras desse Congresso acaba de sair pela Edusp. Nos últimos três anos, o Projeto Nascente também contribuiu para a visibilidade mais globalizadora das Artes na USP. Evidenciou-se o grande número de estudantes de ciências que também fazem arte e a necessária ampliação dos cursos de arte e flexibilização dos currículos para possibilitar que estudantes de Direito, de Engenharia, de Medicina, de Geologia ou de outras áreas possam também freqüentá-los. O Museu de Arte Contemporânea oferece, desde 91 , a cada semestre, uma disciplina de graduaçáo em História e/ou Apreciaçăo da Arte, aberta a todos os estudantes da Universidade, valendo crédito para seus currículos. É muito pouco, mas a concorrência às vagas oferecidas é de cinco para uma.

O interesse pelas Artes é grande entre os alunos da USP. As Semanas de Artes da FAU e da POLI são famosas e até a Faculdade de Farmácia está produzindo exposiçóes. Os Festivais de Teatro e os Corais da Universidade são concorridíssimos. Entretanto, há ainda um longo caminho a percorrer até que as Artes tenham na USP importância equivalente à de outras áreas.

A categoria de artista-em-residência, hoje restrita a um artista por ano no MAC, alimentaria a produção artística se fosse multiplicada na 
USP. O ensino das Artes em todo o mundo tem mostrado os benefícios de uma estrutura que coloque, lado a lado, o artista que se interessa apenas pela produção de Arte e que, eventualmente, aceita passar um semestre ou um ano trabalhando em ateliê aberto aos alunos em uma universidade e $o$ artista, professor de carreira preparado para enfrentar os embates da relação ensino-aprendizagem. Este último sistematiza, e o outro, por ver o estudante năo como um aluno mas como um jovem companheiro que escolheu trabalhar com ele, póe em xeque a profissionalização que a Universidade está produzindo. Maior articulação da prática com a teoria também é desejável e talvez até ter a teoria como reflexão da prática para os artistas e a prática como exercício de reconhecimento para os teóricos e historiadores.

A história das Artes na USP reforça a postura de enfocar a teoria como consciência da prática da Arte ou da pesquisa em Arte, pois a obra de arte - objeto de estudos do artista, do teórico e do historiador foi a primeira preocupação da Universidade de São Paulo no campo das Artes.

As Artes entraram na USP através de um museu, de um acervo de obras de arte. Antes de ensinar arte, a Universidade já tinha o Museu de Arte Contemporânea, de criação anterior à Escola de Comunicaçóes e Artes. Na Europa foi muito comum os museus criarem escolas de Arte, mas é muito raro, no mundo todo, uma universidade ter um Museu de Arte antes de estabelecer o seu ensino. Isso possibilitou uma interface maior da USP com a comunidade artística fora dela. Os primeiros estagiários do MAC eram alunos da FAAP porque a USP náo tinha estudantes de Arte. Até hoje, alunos das mais diversas escolas universitárias de Arte de São Paulo têm acesso à USP através dos estágios no MAC, onde mantêm contato direto com um acervo de fazer inveja a muitas universidades da América do Norte. Das Universidades que conheço, apenas em Yale e Harvard encontrei acervos mais importantes que $o$ nosso. $O$ desenho arquitetônico do Museu da Universidade de Indiana é provavelmente o mais espetacular dos Estados Unidos. Seu arquiteto foi Ieoh Ming Pei, o mesmo do novo Louvre, mas o acervo do novo MAC ainda é mais importante.

É enorme o prestígio que as universidades americanas conferem a seus museus $e$ às Artes. O mesmo náo acontece no Brasil, embora a USP, nos últimos anos, tenha oferecido uma das maiores contribuições às Artes, ao construir a nova sede do MAC. Mas a USP continua a ser a única universidade no Brasil a ter cursos de doutorado em Música, em Teatro, em Poéticas Visuais, em Arte-Educaçăo e em História da Arte. Um único programa de doutorado com vagas necessariamente limitadas 
para atender às expectativas dos egressos de 249 cursos de graduação em Artes no país (Medicina tem apenas 83 ) significa um estrangulamento na formação de pesquisadores para a área. Destes cursos, 132 săo de Licenciatura, isto é, formam os arte-educadores, aqueles profissionais responsáveis em promover o entendimento, a apreciação e a percepção artística e estética assim como a alfabetizaçăo visual $\mathrm{e}, \mathrm{em}$ grande parte, cultural. Portanto, o caso da Arte-Educação é ainda mais grave, pois não há sequer mestrado nessa área em qualquer outra universidade brasileira. A USP é também a única universidade no país que mantém, já há dez anos, um curso de especialização em Arte-Educação e, em 1991, criouse no MAC o único curso permanente de especializaçáo em Estudos de Museu de Arte. Por tudo isso, as Artes na USP, embora muito jovens, com menos de a metade da idade que a Universidade comemora este ano, já contam com muitas conquistas. Foi somente depois da ditadura que a Universidade deixou de tratar as Artes como madrasta, embora ainda falte muito para tratá-las como filhas diletas.

Exemplo da desconsideraçáo pelas Artes na Universidade é o fato de que nos suplementos dedicados aos 60 anos da USP em prestigiados jornais de São Paulo, não houve qualquer mençáo às Artes por parte de nenhum dos articulistas, eminentes professores universitários.

Ana Mne Barbosa é professora do Departamento de Artes Plásticasda Escola de Comunicaçóes e Artes da USP.

Texto extraído do Jornal da USP (21 a 27/3/1994, p. 2). 